Case Reports in
Gastroenterology
Case Rep Gastroenterol 2021;15:365-371

DOI: $10.1159 / 000513397$

Published online: March 12, 2021 (c) 2021 The Author(s)

Published by S. Karger AG, Basel www.karger.com/crg

This article is licensed under the Creative Commons Attribution-NonCommercial 4.0 International License (CC BY-NC) (http://www.karger.com/Services/OpenAccessLicense). Usage and distribution for commercial purposes requires written permission.

\title{
Don't Forget about the Sump! An Uncommon Complication Many Years after a Choledochoduodenostomy
}

\author{
María Fernanda Chimal ${ }^{a} \quad$ Carlos Ernesto Morales ${ }^{b} \quad$ Eric Misael Saucedo ${ }^{b}$ \\ ${ }^{a}$ General Surgery Residency Program, Mexican Faculty of Medicine, La Salle University \\ Mexico, Hospital Angeles Mocel, Mexico City, Mexico; 'bepartment of General Surgery, \\ Hospital Angeles Mocel, Mexico City, Mexico
}

\section{Keywords}

Sump syndrome $\cdot$ Cholangitis $\cdot$ Choledochoduodenostomy $\cdot$ Complication

\begin{abstract}
Bilioenteric anastomoses were common interventions before the rise of minimal invasion procedures, specifically, before endoscopic retrograde cholangiopancreatography. During a choledochoduodenostomy (CDS) the distal part of the common bile duct is excluded from the bile drainage and behaves as a "sump," a poorly drained part that works as a reservoir which is responsible of the development of complications of the bilio-pancreatic tract. The consequent sump syndrome is a rare medical complication that presents a diversity of symptoms, for which there is no well-defined diagnostic algorithm. We present the case of a 72-year-old male patient with multiple comorbidities. He presented to the ER because of recurrent episodes of cholangitis; after having obtained the patient's medical records, lab and image studies, the latter showed pneumobilia. After considering all the results plus the pneumobilia we suspect the presence of this uncommon complication of CDS. The patient was subjected to an unsuccessful endoscopic treatment followed by surgery, after which he showed signs of improvement and adequate evolution till hospital discharge.




\section{Case Reports in Gastroenterology}

\begin{tabular}{l|l}
\hline Case Rep Gastroenterol 2021;15:365-371 \\
\hline DOI: 10.1159/000513397 & $\begin{array}{l}\text { ○ 2021 The Author(s). Published by S. Karger AG, Basel } \\
\text { www.karger.com/crg }\end{array}$ \\
\hline
\end{tabular}

Chimal et al.: Don't Forget about the Sump! An Uncommon Complication Many Years after a Choledochoduodenostomy

\section{Introduction}

Sump syndrome (SS) is a scarcely known medical condition; it is a rare complication of bilioenteric anastomosis performed previously to the era of endoscopic treatments such as endoscopic retrograde cholangiopancreatography (ERCP). Studies have shown that it has a prevalence ranging from 0 to $9.6 \%$, being more frequent after performing a choledochoduodenostomy (CDS) [1,2].

This syndrome is not entirely defined; it results from the accumulation of lithogenic bile, cellular detritus, and gallstones as well as reflux of the duodenal content in the distal part of the common bile duct that has an inefficient drainage - the sump - which results in biliary and pancreatic complications [3,4]. Characteristic clinical features or highly specific laboratory findings that could lead to this concrete diagnosis. Nowadays, in the era of laparoendoscopic procedures, choosing CDS as a first-line treatment is unheard of and its complications, including SS, are almost forgotten, mainly due to the large time interval between procedure and the syndrome's appearance. The primary diagnosis as well as the treatment can be conducted, most of the time, endoscopically by ERCP $[5,6]$.

We present the case of a 72-year-old male patient with SS who had recurrent episodes of cholangitis. The detailed medical history along with pneumobilia in imaging studies led to the suspicion of the syndrome.

\section{Case Presentation}

A 72-year-old male patient arrived at the hospital for the fourth time in the year due to crampy abdominal pain in the right upper quadrant, along with fever and jaundice. Laboratory test upon admission showed hemoglobin $9.8 \mathrm{mg} / \mathrm{dL}$, leukocytes $13.6 \times 10^{3} / \mu \mathrm{L}$, neutrophilia $83 \%$, lymphocytes $10 \%$, glycemia $418 \mathrm{mg} / \mathrm{dL}$, BUN $56.9 \mathrm{mg} / \mathrm{dL}$, urea $122.1 \mathrm{mg} / \mathrm{dL}$, creatinine $2.03 \mathrm{mg} / \mathrm{dL}$, total bilirubin $2.06 \mathrm{mg} / \mathrm{dL}$, direct bilirubin $1.40 \mathrm{mg} / \mathrm{dL}$, indirect bilirubin 0.66 $\mathrm{mg} / \mathrm{dL}$, GOT 526.1 U/L, GPT 349.8 U/L, GGT 1,491.1 U/L, AF $918 \mathrm{U} / \mathrm{L}$, physical examination with positive Murphy sign, without any data of peritonitis. Medical records showed that the patient had a cholecystectomy 15 years ago, a bilioenteric anastomosis 7 years ago due to complex choledocholitiasis associated to a dilatation of the extrahepatic biliary ducts with 3 previous failed attempts for endoscopic resolution; history of acute myocardial infarction with revascularization therapy, and secondary ischemic heart disease, systemic arterial hypertension, and type 2 diabetes mellitus, all of them under oral treatment. CT reported pneumobilia and a suggestive image of duodenum-bile duct communication (shown in Fig. 1). ERCP was performed again, observing the CDS in the first portion of the duodenum with a diameter of $1 \mathrm{~cm}$, with inability to cannulate the papilla due to fibrosis (shown in Fig. 2 and Fig. 3). Considering the imaging findings, the recurrent cholangitis episodes and the previous history of a CDS, the diagnosis of SS was reached.

Due to the patient's medical background and the failure of several occasions in the endoscopic way, definitive surgical treatment was the choice. The patient was submitted to a distal gastrectomy with Roux-en-Y gastrojejunostomy, with adequate post-surgical evolution, and he was discharged from the hospital a week later.

\section{Karger'=}




\section{Case Reports in Gastroenterology}

Case Rep Gastroenterol 2021;15:365-371

DOI: 10.1159/000513397

(c) 2021 The Author(s). Published by S. Karger AG, Basel www.karger.com/crg

Chimal et al.: Don't Forget about the Sump! An Uncommon Complication Many Years after a Choledochoduodenostomy

\section{Discussion and Conclusion}

Bilioenteric anastomoses were common procedures until the advent of endoscopic methods, specifically ERCP [1]. Among the indications for performing a CDS we can find choledocholithiasis unresolved by ERCP or bile duct exploration, benign biliary strictures, malignant neoplasms of the biliopancreatic tract, and even biliary reconstructions for transplants $[5,7]$. Nowadays, in the era of laparoendoscopic procedures, bilioenteric anastomoses are rarely used as first-line treatment choices, and their complications, including SS, are scarcely found [8].

This syndrome is an infrequent complication of the CDS with a reported prevalence of 0 9.6\%; classically it occurred more frequently after a side-to-side CDS; however, there is no difference reported with the side-to-end variation [2].

The most complete definition of the syndrome covers the combination of clinical and radiological findings [9]. This "sump" is formed from the portion of the common bile duct that lies between the papilla of Vater and the choledochoenteric anastomosis; this distal segment of the common bile duct results in a deposit with insufficient drainage where the intraluminal content is refluxed in the distal duct and anastomosis (shown in Fig. 4). Consequently sludge or food debris trapped in this non-functional reservoir above the papilla results in bacterial infections, biliary stasis, formation of new gallstones, and even dysplastic changes in the mucosa of the common bile duct $[3,5,10]$. The clinical presentation is non-specific, it varies most of the time, but is recurrent. Within the symptoms, we can find pain in the right upper quadrant, jaundice, fever and other findings that correspond with cholangitis, liver abscesses, and pancreatitis plus other stemming complications $[1-5,11]$. Among the imaging studies that are helpful for the diagnosis, we find, depending on accessibility, US, TC, and MRI. The radiological signs of suspicion are detritus and gallstones in the distal common bile duct, and the presence of pneumobilia is another key element to establish the diagnosis; air in the biliary tree is mainly present due to carcinoma, sphincterotomy, or bilioenteric anastomosis. In the case of a previous CDS, it can serve as a sign of a functional anastomosis, especially if we do not have the whole surgical history of our patient [3].

Diagnosing SS is very difficult due to the lack of specific criteria, along with the time interval between the surgery and the syndrome's first manifestations. Obtaining a detailed medical record that also includes migration history (for those patients who migrated from countries where this type of surgery is still performed as first choice and ERCP is not always available), the recurrent signs and symptoms, and extension studies with suggestive findings should lead us to considering it [11-13].

The main goal of the treatment is to improve the biliary drainage from the distal common bile duct to the anastomosis apart from treating the underlying conditions. Surgical treatment was the only available option until recent times; with the advancement of minimally invasive procedures, there is a diversity of available options, such as performing an endoscopic sphincterotomy or a sphincteroplasty with or without dilatation of the anastomosis, and even the closure with a septal occlusion device (Amplatzer) in patients who are not eligible for surgery or refuse it $[1,4,13,14]$. The surgical options available to patients with refractory SS or those for which endoscopic treatment is not viable, are limited. Among the described techniques, we found sphincteroplasty with closure of the choledochoenterotomy, conversion to another biliary diversion such as a hepaticojejunostomy, or, as in our case, distal gastrectomy with Rouxen-Y gastrojejunostomy [4, 9, 14, 15]. In each case, management must be individualized to break the reservoir-stasis-reflux and infection cycle, considering the anatomical modifications

\section{Karger's'}




\section{Case Reports in Gastroenterology}

\begin{tabular}{l|l}
\hline Case Rep Gastroenterol 2021;15:365-371 \\
\hline DOI: 10.1159/000513397 & $\begin{array}{l}\text { @ 2021 The Author(s). Published by S. Karger AG, Basel } \\
\text { www.karger.com/crg }\end{array}$ \\
\hline
\end{tabular}

Chimal et al.: Don't Forget about the Sump! An Uncommon Complication Many Years after a Choledochoduodenostomy

that each procedure represents along with the necessary post-surgical follow-up. Finally, there is no evidence that supports a laparoscopic approach over an open method and vice versa.

Nowadays, CDS has been replaced by ERCP. SS is a rare complication of the former and has a wide clinical range of presentation; sensible, yet unspecified, radiological findings make it an important differential diagnosis to be considered as a biliopancreatic pathology. Knowing about the existence of this syndrome is fundamental since we not only deal with the complications of procedures performed years back, but also with those present due to the inaccessibility to endoscopic treatments.

\section{Statement of Ethics}

The Research Ethics committee of the Angeles Mocel Hospital has approved the lack of written informed consent for publication of the data and images obtained of the medical record of the patient. During the committee's review, it was concluded that the information is adequately supported and lacks conflicts of interest. This is established on the document number 0212/2020-1.

\section{Conflict of Interest Statement}

The authors have no conflicts of interest to declare.

\section{Funding Sources}

The authors disclose no sponsorship or funding arrangements relating to their research.

\section{Author Contributions}

Each of the authors contributed equally in conceiving the idea for the case and the research and helped to draft the manuscript and the images. All authors read and approved the final manuscript.

\section{References}

1 Ancha HR, Maple JT. Long-term results from endoscopic choledochoduodenostomy closure using a cardiac septal occluder device in a patient with refractory sump syndrome. Gastrointest Interv [Internet]. 2013;2(2):121-3.

2 Suliman MS, Singh MM, Zaheer K, Malik SU, Abu-Hashyeh A. Is It Really SUMP Syndrome? A Case Report. Cureus. 2019 Oct;11(10):e5837.

3 Khan TF, Sherazi ZA, Muniandy S, Mumtaz M. Recurrent pyogenic cholangitis: 'sump syndrome' following choledochoduodenostomy. Trop Doct. 1997 Jan;27(1):51-2.

4 Mavrogiannis C, Liatsos C, Romanos A, Goulas S, Dourakis S, Nakos A, et al. Sump syndrome: endoscopic treatment and late recurrence. Am J Gastroenterol. 1999 Apr;94(4):972-5.

5 Fettig DM, Martínez Alcalá A, Schwingel GE, Mönkemüller K. Cholangitis many years after choledochoduodenostomy [Internet]. Gastrointest Endosc. 2017 Feb;85(2):452.

\section{Karger'=}




\section{Case Reports in Gastroenterology}

\begin{tabular}{l|l}
\hline Case Rep Gastroenterol 2021;15:365-371 \\
\hline DOI: 10.1159/000513397 & $\begin{array}{l}\text { @ 2021 The Author(s). Published by S. Karger AG, Basel } \\
\text { www.karger.com/crg }\end{array}$ \\
\hline
\end{tabular}

Chimal et al.: Don't Forget about the Sump! An Uncommon Complication Many Years after a Choledochoduodenostomy

6 Qadan M, Clarke S, Morrow E, Triadafilopoulos G, Visser B. Sump syndrome as a complication of choledochoduodenostomy. Dig Dis Sci. 2012 Aug;57(8):2011-5.

7 Marbet UA, Stalder GA, Faust H, Harder F, Gyr K. Endoscopic sphincterotomy and surgical approaches in the treatment of the 'sump syndrome'. Gut. 1987 Feb;28(2):142-5.

8 Zeuge U, Fehr M, Meyenberger C, Sulz MC. Mind the sump! - diagnostic challenge of a rare complication of choledochoduodenostomy. Case Rep Gastroenterol. 2014 Nov;8(3):358-63.

9 Caroli-Bosc FX, Demarquay JF, Peten EP, Dumas R, Bourgeon A, Rampal P, et al. Endoscopic management of sump syndrome after choledochoduodenostomy: retrospective analysis of 30 cases. Gastrointest Endosc. 2000 Feb;51(2):180-3.

10 Leppard WM, Shary TM, Adams DB, Morgan KA. Choledochoduodenostomy: is it really so bad? J Gastrointest Surg. 2011 May;15(5):754-7.

11 Okamoto H, Miura K, Itakura J, Fujii H. Current assessment of choledochoduodenostomy: 130 consecutive series. Ann R Coll Surg Engl. 2017 Sep;99(7):545-9.

12 Abraham H, Thomas S, Srivastava A. Sump Syndrome: A Rare Long-Term Complication of Choledochoduodenostomy. Case Rep Gastroenterol. 2017 Aug;11(2):428-33.

13 Aguirre-Olmedo I, Cuendis-Velázquez A, Morales-Chávez CE, Torres-Ruiz MF, Rojano-Rodríguez ME, Cárdenas-Lailson LE. Coledocoduodenoanastomosis laparoscópica como opción terapéutica en coledocolitiasis compleja. Cir Cir. 2013 Mar-Apr;81(2):118-24.

14 Granata A, Amata M, Martino A, Ligresti D, Li Petri S, Ricotta C, et al. Mini-invasive treatment of sump syndrome: OverStitch choledochoduodenostomy revision. Endoscopy. 2019 Nov;51(11):E337-8.

15 Ravikanth R, Kamalasekar K. Imaging in sump syndrome: A rare complication of choledochoduodenostomy. Indian J Radiol Imaging. 2019 Apr-Jun;29(2):229-31.

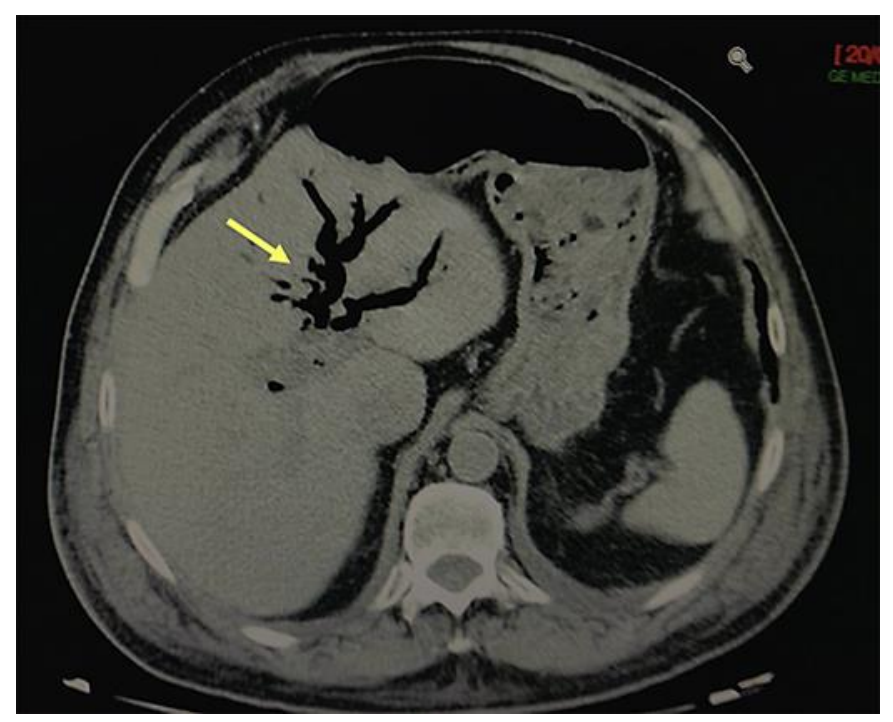

Fig. 1. Abdominal CT showing biliary dilation and intrahepatic pneumobilia (arrow). 
Case Reports in Gastroenterology

\begin{tabular}{l|l}
\hline Case Rep Gastroenterol 2021;15:365-371 \\
\hline DOI: 10.1159/000513397 & $\begin{array}{l}\text { @ 2021 The Author(s). Published by S. Karger AG, Basel } \\
\text { www.karger.com/crg }\end{array}$ \\
\hline
\end{tabular}

Chimal et al.: Don't Forget about the Sump! An Uncommon Complication Many Years after a Choledochoduodenostomy

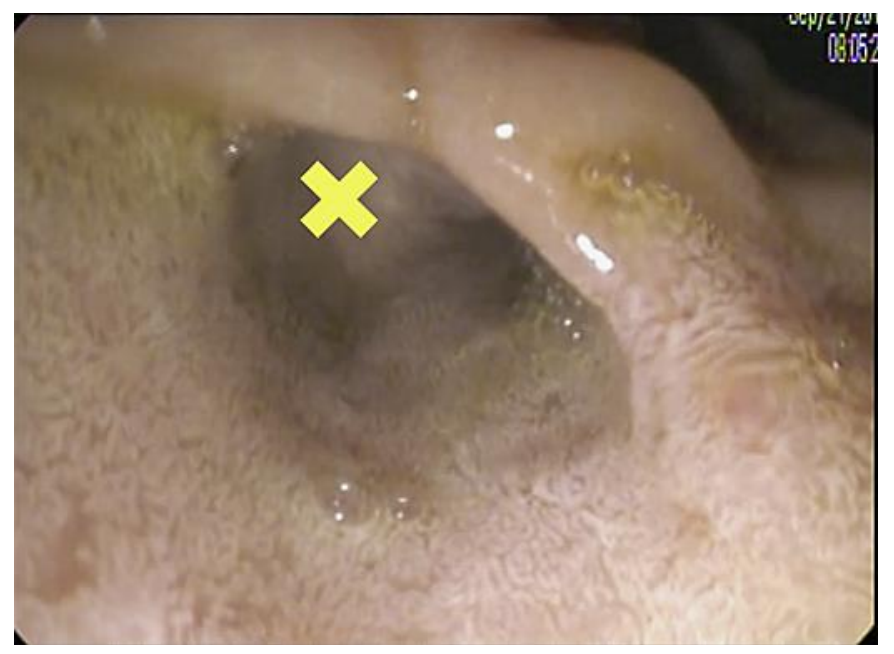

Fig. 2. Endoscopic retrograde cholangiopancreatography - endoscopic view showing choledochoduodenostomy (cross).

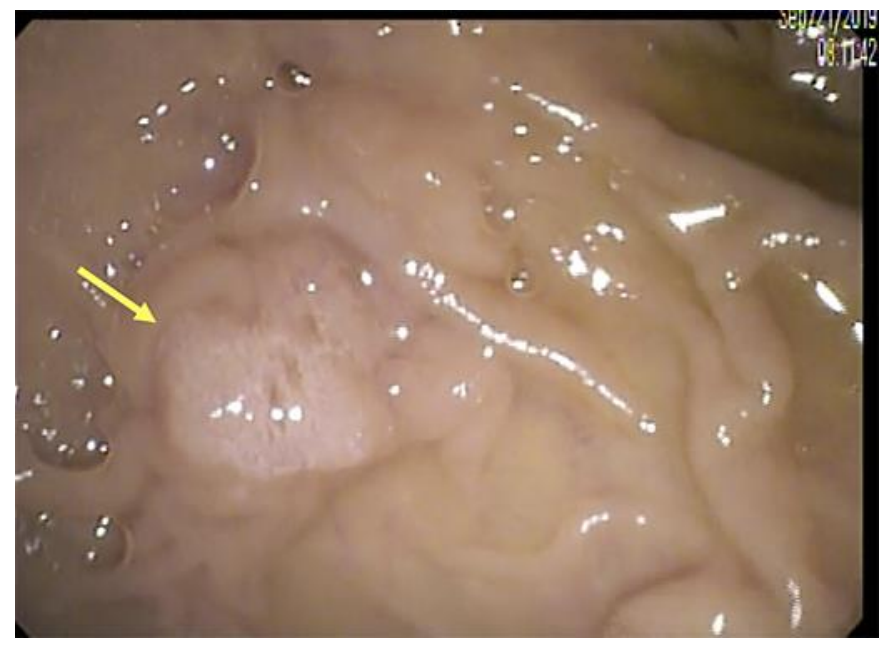

Fig. 3. Endoscopic retrograde cholangiopancreatography - endoscopic view showing the fibrous papilla (arrow).

\section{Karger'=}


Case Reports in Gastroenterology
Case Rep Gastroenterol 2021;15:365-371

DOI: $10.1159 / 000513397$

(c) 2021 The Author(s). Published by S. Karger AG, Basel www.karger.com/crg

Chimal et al.: Don't Forget about the Sump! An Uncommon Complication Many Years after a Choledochoduodenostomy

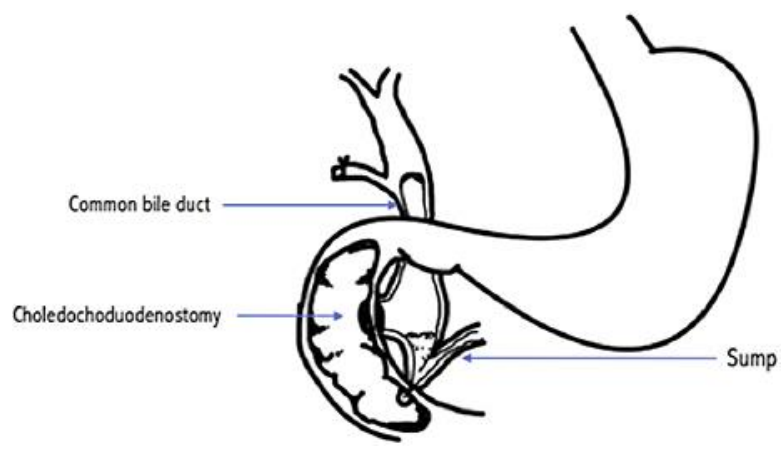

Fig. 4. Schematic representation of a choledochoduodenoanastomosis and the "sump" formed by the distal poorly drained choledochus. 